\title{
Exposure to Wood Smoke Pollution During Pre-Gestational Period of Rat has Effects on Placenta Volume and Fetus Size
}

\author{
La Exposición a la Contaminación por Humo de Leña Durante el Período Pregestacional \\ de la Rata tiene Efectos sobre el Volumen de la Placenta y el Tamaño del Feto
}

Salinas, Paulo'; Veuthey, Carlos²; Rubio, Ignacio ${ }^{3}$; Bongiorno, Anthony ${ }^{4} \&$ Romero, Ingrid $^{5,6}$

SALINAS, P.; VEUTHEY, C.; RUBIO, I.; BONGIORNO, A. \& ROMERO, I. Exposure to wood smoke pollution during pregestational period of rat has effects on placenta volume and fetus size. Int. J. Morphol., 38(5):1356-1364, 2020.

SUMMARY: Studies in humans showed that prenatal exposure to urban air pollution (AP) influences fetal development, and increases the incidence of adverse pregnancy outcomes and some diseases in postnatal life. However, most of these were performed in environments where the main source of environmental particulate matters (PM) emission is diesel combustion by motor vehicles and industries, thereby ignoring the effects produced by wood smoke pollution. We hypothesized that morphological changes in the placenta could contribute to the reduction in fetal size associated with different periods of exposure to AP produced by wood smoke pollution prior to and during pregnancy. The objective of the study was to investigate the quantitative effects of long-term exposure to environmental levels of wood smoke pollution on the macroscopic and microscopic morphology of the placenta in rats. To test this, pregnant rats were exposed during pregestational and gestational periods to wood smoke pollution in indoor and outdoor environments. At 19 days of gestation, the placentas were obtained by caesarean and were prepared for histological, planimetric and stereological analysis. The volume and proportions of the placental compartments were estimated. In addition, stereological estimators in fetal capillaries were calculated in the labyrinth region. Crown rump length, fetus weight and litter weight were influenced by pregestational and gestational exposure periods. Exposure to wood smoke pollution during pregestational period has significant effect on the volume of the placenta, and consequently on fetal height. In conclusion, this study demonstrated that long-term outdoor exposure to wood smoke pollution from residential heating affects fetal health, decreasing the absolute volume of the entire placenta and the placental interface between the mother and fetus, decreasing the total volume of blood vessels present in the labyrinth region ofthe placenta and affecting the size of the fetus.

KEY WORDS: Pollution; Smoke; Wood Smoke; Pollution; Placenta; Stereology; Rat; Temuco.

\section{INTRODUCTION}

More than $80 \%$ of people living in urban areas are exposed to air quality levels that exceed the World Health Organization limits (WHO, 2018a; maximum exposure daily mean level of PM2.5: $25 \mathrm{mg} / \mathrm{m}^{3}$ ). As urban air quality declines, the risk of stroke, heart disease, lung cancer, and chronic and acute respiratory diseases increases for those who live in these areas. Particulate matter (PM) is the most problematic pollutant in terms of harm to human health and it represents a serious public health problem, with harmful effects on health have been reported worldwide (WHO, 2018b). There is currently ample evidence confirming that environmental air pollution (AP) negatively affects human health. Most studies on ambient AP have focused their efforts on describing air quality datasets, epidemiological history, mortality, and respiratory/cardiac mobility in the population (Schwartz \& Marcus, 1990; Dockery et al., 1996). Some age groups have been shown to be more likely to present clinical or susceptible signs than the general adult population (Saldiva et al., 1995). The opposite extreme occurs with children's health, since respiratory signs and hospital data suggest that this age group, like the elderly, are more vulnerable to environmental AP (AP) than the rest of the general population (Dockery \& Pope, 1994; Heinrich et al., 1999; Schwartz et al., 1994). The background obtained from environmental epidemiology and reproductive outcomes research are relevant indicators of threats to the general health

\footnotetext{
${ }^{1}$ Institute of Biology, Faculty of Sciences, Pontificia Universidad Católica de Valparaíso, Valparaíso, Chile.

${ }^{2}$ Center for Research in Dental Sciences, Faculty of Dentistry, Universidad de La Frontera, Temuco, Chile.

${ }^{3}$ School of Medical Technology, Faculty of Sciences, Pontificia Universidad Católica de Valparaíso, Valparaíso, Chile.

${ }^{4}$ Department of Biology, Middlebury College, Vermont, United States.

${ }_{5}^{5}$ Doctorate Program in Morphological Sciences, Universidad de La Frontera, Temuco, Chile.

${ }^{6}$ Faculty of Health Sciences, Department of Diagnostic Processes and Evaluation, School of Nutrition, Universidad Católica de Temuco, Temuco, Chile.
} 
and development of newborns and babies, as there is emerging evidence that AP is also associated with a high risk of adverse pregnancy outcomes (Maisonet et al., 2001, 2004; Glinianaia et al., 2004; Veras et al., 2008), such as low birth weight (Gouveia et al., 2004), intrauterine growth retardation, and slow growth in the first years oflife which influence the state of later health in the adult life of people, including increased mortality and morbidity in childhood and a high risk of hypertension, coronary heart disease and diabetes in adulthood (Barker, 1989, 1995; Osmond \& Baker, 2000). Studies of the effects of AP on reproductive outcomes have been important in environmental epidemiology and in experimentation (Srám et al., 2005). Most epidemiological reports state that exposure to high environmental levels of AP (mainly PM2.5 particulate matter) affects fetal development (Mohorovic, 2004; Ritz et al., 2007). Different study designs, statistical analysis, and indications of some risk factor's (maternal smoking, gestational age, and socioeconomic factors) presented in these investigations have suggested that the reported associations are causal.

In large urban centers around the world (Sao Paulo, Tokio, Los Angeles, Ciudad de Mexico, etc), studies have been carried out on atmospheric AP and its consequences (Veras et al.; Oyarzún, 2010; Romieu et al., 2012). Main source of emission of PM and toxic substances is the combustion of diesel derived from motor vehicles and industries. In small and medium-sized urban centers (like cities of southern Chile), air pollution studies and their impact on health has not been studied yet. For decades, a causal relationship has been suspected between AP and infertility (Carré et al., 2017). However, there is no conclusive scientific evidence to support this. Most of the studies describe epidemiological antecedents or effects on the cardiorespiratory system associated with AP whose main source of emission of PM and toxic substances is the combustion of diesel and industrial engines, ignoring the effects of wood smoke pollution produced by residential heating. As an important source of emission, the issue of wood has received special attention in recent years in social networks, the scientific community and those responsible for decision making. In 2016, the annual environmental PM2.5 concentration was measured in several cities of Southern Chile through the National Air Quality Information System (SINCA). This study showed that its annual concentrations were considerably high $\left(>30 \mathrm{mg} / \mathrm{m}^{3}\right)$. Evidence shows that in Chile nearly two million people are exposed to a high risk of AP.

Wood smoke pollution (humidity above $25 \%$ ) produced by residential heating is a serious problem affecting South-Central Chile (below $35^{\circ} \mathrm{S}$; Sanhueza et al., 2006; Cereceda-Balic et al., 2012; Schueftan \& González, 2013;
Schiappacasse et al., 2013; Villalobos et al., 2017). This is caused by the excessive and widespread use of wood - one of the cheapest fuels available - for heating in inefficient stoves and in homes with poor thermal insulation. Padre Las Casas, Osorno, Coyhaique, Valdivia and Temuco have the highest pollution rates in Latin America, and together with the cities of Santiago, Linares, Andacollo and Rancagua, are among the 20 most polluted cities in the continent. This was reported by the latest report on Urban Air Quality released by the World Health Organization (WHO, 2018a) and World Air Quality Report, which analyzes the data of 4,357 cities in 108 countries, from 2010 to 2018. Also, the latest data compiled in the 2019 World Air Quality Report (IQAir, 2020), and interactive World's Most Polluted Cities ranking, prepared in collaboration with Greenpeace, reveals the state of PM2.5 pollution in Chile. In 2019, "TemucoPadre Las Casas" was the most polluted city of South America and for the last 10 years Temuco has remained within the top-5 most polluted cities in South America (Cereceda-Balic et al.; WHO, 2018a; IQAir AirVisual, 2019).

"Temuco-Padre Las Casas" is located 670 kilometers south of the capital of Chile, Santiago, and 80 kilometers from the Pacific Ocean. It has approximately 270,000 inhabitants, and its economy is based on agro-industry, forestry and services (Cereceda-Balic et al.). It was declared a "saturated zone", presenting episodes of high PM concentration, which have been systematically exceeding values defined by Chilean national air quality standards (NAQS) and World Health Organization (WHO, 2018a) standards. In Chile, AP in some cities is stationary, and generally originates from the domestic heating habits of its citizens (Boso et al., 2019; Reyes et al., 2019). According to the latest PM10 emissions inventory published in the city of Temuco, wood smoke pollution is the main source of AP, accounting for $93 \%$ of emissions, which is considered by Díaz-Robles et al. (2008) as a city with a "single emission source" (monosource). Firewood burnt in stoves with inefficient technology generates a large amount of PM emissions in the ambient air. The negative health effects of this type of environmental AP are undisputed. Sanhueza et al. (2009) published an epidemiological study in which they reported a strong association between PM10 and daily mortality during the period (1997-2006), in people older than 65 years with cardiovascular diseases, representing $6 \%$. Emergency room visits for acute respiratory infections represented $28 \%$. Rey-Ares et al. (2016) analyzed epidemiological data from Temuco and concluded that exposure to wood smoke pollution may increase the risk of perinatal morbidity and lower tract respiratory infection in children younger than 5 years of age. In order to reduce the concentration of PM2.5 and PM10, government authorities 
have shown concern in promoting the efficient use of vehicles and combustion of firewood, implementing decontamination plans and imposing restrictions on the use of wood-stoves heaters, promoting access to cleaner heating technologies. However, these efforts have not been successful (MINSAL, 2015). In "Temuco-Padre Las Casas" (1587 annual deaths registered, with $24 \%$ due to cardiovascular disease and $11 \%$ to respiratory causes). There are no experimental studies that associate AP with health effects, and specifically on the reproductive system. We hypothesized that morphological changes in the placenta could contribute to the reduction in fetal size associated with different periods of exposure to AP produced by wood smoke pollution prior to and during pregnancy. The objective of the study was to investigate the quantitative effects of long-term exposure to environmental levels of AP produced by wood smoke pollution on the macroscopic and microscopic morphology of the placenta in rats.

\section{MATERIAL AND METHOD}

All animal experiments should be carried out in accordance with the Law 20.380 in accordance with national and institutional guidelines for animal welfare and the National Institutes of Health Guide for the Care and Use of Laboratory Animals (NIH Publications No. 8023, revised 2011) (National Research Council (US) Committee for the Update of the Guide for the Care and Use of Laboratory Animals, 2011). The animals were treated humanely, with due consideration being given to the alleviation of distress and discomfort.

Site of exposure. The experiments were carried out in Temuco (southern Chile) in the Center for Morphological and Surgical Studies (CEMyQ) of the Faculty of Medicine at the University of La Frontera (38 $44^{\prime} 59.4^{\prime \prime S}$ $\left.72^{\circ} 37^{\prime} 07.8^{\prime \prime} \mathrm{W}\right)$. Biomass-burning sources was present in this area, mainly wood combustion for residential heating. We assessed the association between indoor and outdoor AP exposure on placenta using a time-stratified case-crossover design, which has been widely used for investigating the effects of AP on various health outcomes. The study was conducted during the southern hemisphere winter season, from July 15th to October 30th, 2018.

Exposure Conditions and Air Analysis. The exposure was simulated using two different environments side by side, modified based on Veras et al. The outdoor environment consisted of an open-air chamber (outdoor chamber) that received ambient air at a flow rate of $22 \mathrm{~m}^{3} \mathrm{~m}^{-1}$. The indoor environment consisted of a closed chamber (indoor chamber) that received ambient air (ventilation) for $2 \mathrm{~h} /$ day ( 4 periods of $30 \mathrm{~m}$ ) at a flow rate of $22 \mathrm{~m}^{3} \mathrm{~m}^{-1}$. Inside the chambers, the rats were kept in identical environmental conditions of temperature and humidity. Both chambers had dimensions of $5.0 \mathrm{~m} \times 5.0 \mathrm{~m} \times 2.1 \mathrm{~m}$ high. In the outdoor chamber, the air entered freely through the base of the chamber and was distributed evenly inside it before leaving freely through a window at the top. Meanwhile, the windows of the indoor chamber were kept closed $20 \mathrm{~h}$ day, reducing the passage of ventilation air from outside to inside. The $24 \mathrm{~h}$ concentrations of PM2.5 and PM10 inside both chambers were measured at a single site using an ambient continuous monitor (HT9600, Guangdong, China). The concentration of the outside environment was determined by Beta Attenuation Monitors (Raja et al., 2017) using MetOne 1020 BAMs (The Met One Instruments, Inc. model BAM-1020). Concentrations of $\mathrm{CO}$ (8-h mean) was determined by a nondispersive infrared method. All samples were collected by "Algoritmos y Mediciones Ambientales SpA" from the "Las Encinas Monitoring Station" of the National Air Quality Information System, which is located just 200 meters from the exposure chamber site and was provided online by the National Air Quality Information System (https:// sinca.mma.gob.cl) for use in this research.

Animals. The Sprague-Dawley rats $(n=48)$, second generation (G2), belonging to the Biotereum of the Center for Morphological and Surgical Studies (CEMyQ) of the Faculty of Medicine of the Universidad de La Frontera, in Temuco, Chile were used. The rats were fed a balanced diet and water ad libitum. The animals received continuous veterinary assistance. Euthanasia procedure (unrelated to this research) was carried out in accordance with Law 20,380 (MINSAL, 2009) and the AVMA Guidelines on Euthanasia (Nolen, 2011). In addition, to reduce the "father bias", only males that were gestated and reared in an indoor environment were used.

Exposure protocols. We use an environmental pollution exposure model based on Veras et al. We exposed two generations of rats to AP by wood smoke pollution and used the second generation $(\mathrm{G} 2)$ to investigate the effects caused by prenatal exposure from previous generations. We used four groups of primiparous G2 rats, continuously exposed from birth to caesarean day, 19 days post fecundation (dpf). G2 rats were continuously exposed to an indoor (In) or outdoor (Out) environment from pregestational period (birth to the first day of pregnancy), and each group was subsequently subdivided into two exposure groups (outdoor or indoor, $n=12$ ) during the gestation period. Reproductive maturity was evaluated by vaginal cytology (Diff Quick, Hartman) and the 
observation of preovulatory follicles. G2 rats were obtained using the following protocol: 20-day-old rats (G0: 10 males and 10 females) belonging to the CEMyQ Bioterium were kept in indoor (In: 5 couples) and outdoor (Out: 5 couples) chambers. The rats mated in their respective chambers at 60 days of age. The G1 were obtained from full-term gestations that developed in both chambers and subsequently remained in them. Upon reaching reproductive maturity, mating of 10 pairs of G1rats (5 couples per chamber) was performed. The $\mathrm{G} 2$ rats were obtained from the mating period of 10 pairs of G1 rat kept (In: 5 couples; Out: 5 couples) kept in cages until they reached the reproductive age (60 days approx.). To determine the stage of the estrous cycle, daily vaginal cytology was performed. The presence of a vaginal plug and sperm in the vagina was used to assess whether mating occurred and determine the first day of gestation. After mating, the females were divided into four study groups, defined as: Indoor/Indoor (In/In; female G2 rats that were raised and also presented a full-term pregnancy in an indoor exposure chamber), Indoor/Outdoor (In/Out; female G2 rats that were raised in outdoor chamber and presented a full-term pregnancy in an indoor exposure chamber) and Outdoor/ Indoor (Out/In; female G2 rats that were raised in outdoor chamber and presented a full-term pregnancy in an indoor exposure chamber) and Outdoor/Outdoor (Out/Out; female G2 rats that were raised and also presented a full-term pregnancy in an indoor exposure chamber). All the rats G2 included in this study demonstrated at least one estrus.

Histological processing and digital images. Complete placenta samples (Fig. 1) were obtained from 48 healthy adult female $\mathrm{G} 2$ rats subjected to cesarean $19 \mathrm{dpf}$ from each study group. No gross abnormalities were present. Six placenta per litter were randomly selected, during the collection they were measured with caliper and subsequently fixed with $4 \%$ formalin buffered for 24 hours and subsequently subjected to histological processing. Sections of placenta were obtained and fixed in $10 \%$ formaldehyde for $72 \mathrm{~h}$ at room temperature $\left(22{ }^{\circ} \mathrm{C}\right)$. Then, they were dehydrated in a series of alcohols, clarified in xylol and embedded in Paraplast (Paraplast Plus embedding medium; melting point: $54^{\circ} \mathrm{C}$; Sigma-Aldrich Chemical Co., St Louis, MO, USA). Serial sections were made ( $5 \mu \mathrm{m}$ thick) with a motorized rotary microtome Leica RM2255 (Leica Microsystems, Switzerland). Then, the sections were rehydrated, immersed in xylol (10 min), exposed to descending concentrations of ethanol $(100 \%, 96 \%, 80 \%$ and $70 \%$, all $15 \mathrm{~s}$ ) and finally distilled water. Crosshistological sectional of placenta were stained with hematoxylin and eosin and scanned using a Motic Easy Scan ${ }^{\circledR}$ Pro Digital slide scanner (Motic Instrument Inc, Canada) to produce fully digital panoramic views.

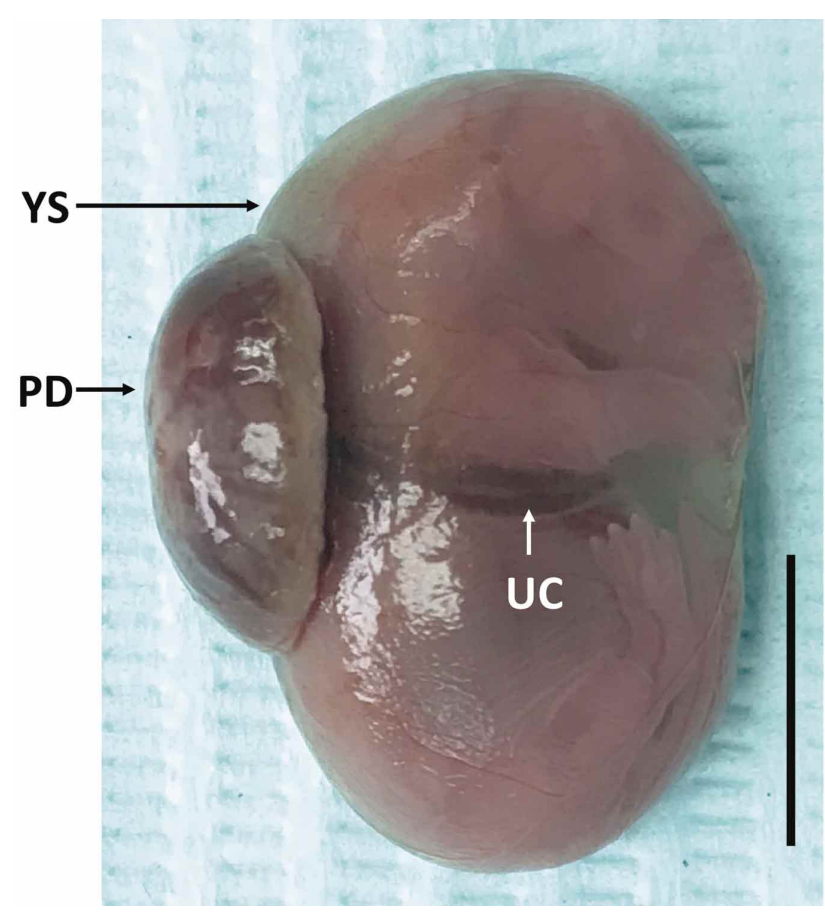

Fig. 1. Photograph of the fetus and its placenta at gestational day 19. Fetus after removal from the uterus. Note the yolk sac (choriovitelline placenta), which acts as a transient placenta in the early stage of the gestation. YS: yolk sac; PD: placenta; UC: umbilical cord $(\mathrm{Bar}=1 \mathrm{~cm})$.

\section{Fetal and placental analysis}

Morphometry. All fetal (Fig. 2A) and tissue measurements were performed in cross-histological sectional images with ImageJ software (ImageJ32 v1.51p). Cross-sectional areas of placenta were obtained by point counting and the areal equivalents of test points.

Volume measurement, planimetry and stereology. The total volume of placental disc (Fig. 2B) was estimated using the Cavalieri principle. In order to view each placenta cross section in its entirety, selected SUR slides were photographed using a $4 X$ objective lens. An estimation of 6 placentas per group were used. A series of transversal cross-sections was generated for each placenta. For planimetry, the fractional area (\%) of the placenta components (labyrinth, junctional zone and decidua; Fig. 2C) were calculated by light microscopy at $1 \mathrm{X}, 2 \mathrm{X}$ and $4 \mathrm{X}$ magnifications. For stereology, sampling and acquisition of unbiased stereological estimators were performed. Serial histological sections $(300 \mu \mathrm{m}$ intervals) $5 \mu \mathrm{m}$ thick were analyzed; each stereological data was estimated by examining 5 microscopic fields per sample (Mayhew, 2009). For unbiased stereology, in the labyrinth, the volume density $\left(\mathrm{V}_{\mathrm{v}}[\%]\right.$; estimated by point counting), surface densities $\left(\mathrm{S}_{\mathrm{v}}\left[\mathrm{mm}^{2} / \mathrm{mm}^{3}\right]\right.$; estimated by intersection 

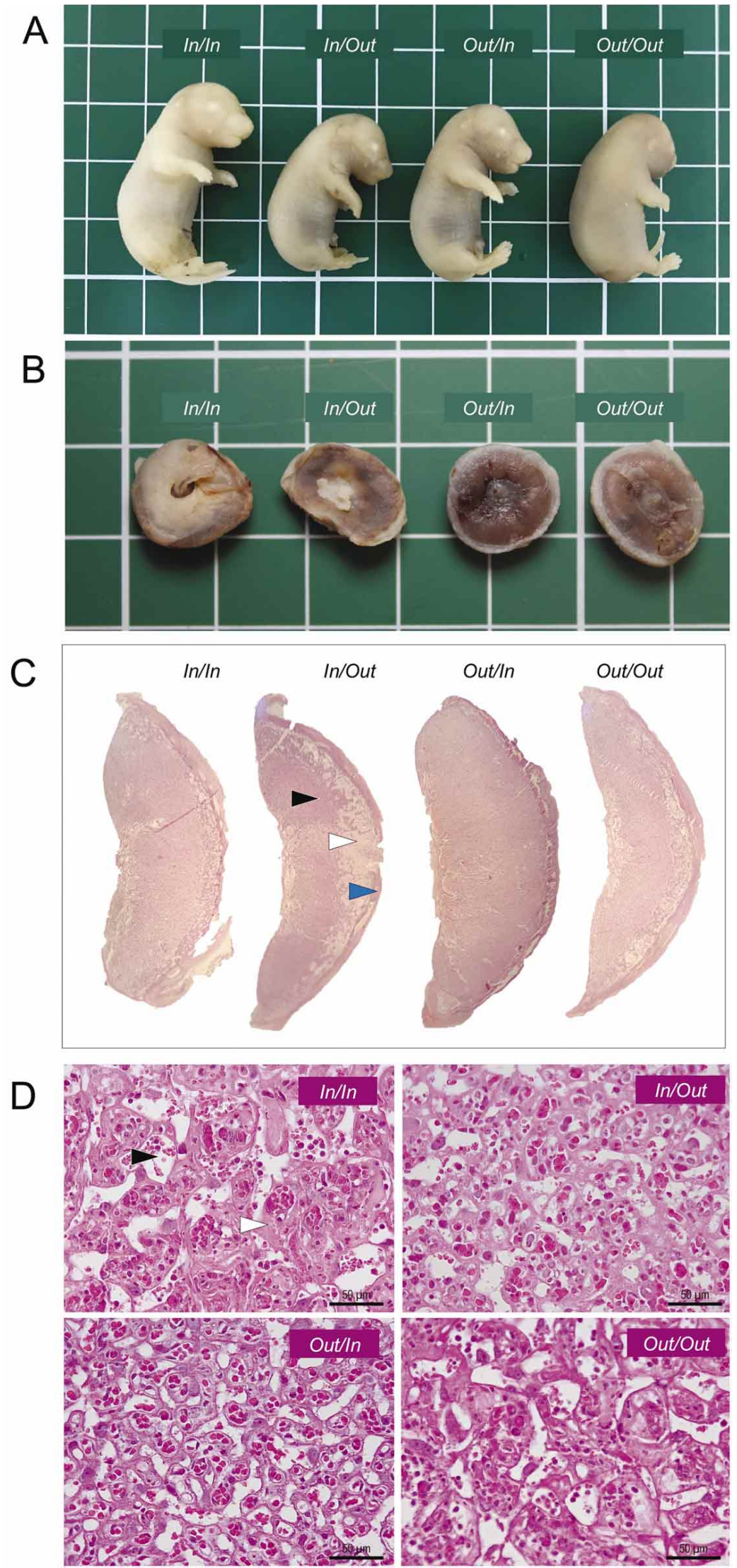

counting) as well as longitudinal density $\left(\mathrm{L}_{\mathrm{v}}\right.$; $\left[\mathrm{mm} / \mathrm{mm}^{3}\right]$; estimated by intersection counting) of the vessels were calculated by light microscopy at 40X; Fig. 2D). The $\mathrm{M}_{64}$ test system provided by the STEPanizer Stereological Tool software (Tschanz et al., 2011) was used, utilizing 64 test points; the test line measures $32 \mathrm{~d}$ and the test area measures $36.36 \mathrm{~d}^{2}$. The overlapping program analyzed images from labyrinth. Total volumes of labyrinth, junctional zone, and decidua within the placenta were determined by multiplying the mean proportion of each tissue within each placenta by the total volume of each respective placenta. All stereological and planimetric evaluations considered tissue deformation (DorphPetersen et al., 2001). All measurements were performed by two trained observers, each using his own microscope and computer software, blinded to the identity of the groups.

Statistical analyses. Data were expressed as mean \pm standard deviation (SD) and (coefficient of variation; \%). The data distributions of continuous variables were tested for normality by means of the D'Agostino Pearson Test. Morphometric, planimetric and stereological data (total placenta volume, volumes of placenta components and volumes of labyrinth zone components) were analyzed by one-way ANOVA among the three groups and by Tukey's post-test of multiple comparisons. In addition, the coefficient of variation (\%) was used to compare the variability between groups. Statistical significance for all of hypotheses tests was set at $p<0.05$ and $95 \%$ Confidence Interval. The data analysis was performed using GraphPad Prism 8.0 software for Mac OS X (GraphPad Software, San Diego CA).

Fig. 2. (A) Fetal gross appearance on gestation day 19. (B) Gross appearance of rat placenta (hemotrichorial type) on gestation day 19. (C) Subgross histologic anatomy of the central section of the rat placenta on gestation day 19 (Hematoxylineosin). Black arrow: labyrinth zone; white arrow: basal zone; blue arrow: decidua. (D) Histological appearance of the labyrinthine compartment of the rat placenta. Black arrow: fetal capillary; white arrow: trophoblastic cell (hematoxylin-eosin; $\mathrm{Bar}=50 \mu \mathrm{m})$ 


\section{RESULTS}

Normality test showed the data was normally distributed. Therefore, a parametric test was used for statistical analysis. The ANOVA test and Tukey's post hoc tests of multiple comparisons were used to identify significant differences on length, planimetric and stereological variables in foetuses and placenta.

Exposure assessment. The daily mean outdoor levels of PM 2.5, PM10 and CO in Temuco-Padre Las Casas during the experimental period were $47.74 \mathrm{mg} / \mathrm{m}^{3}( \pm 35.9 ; \mathrm{CV}=86.69$ $\%), 56.4 \mathrm{mg} / \mathrm{m}^{3}( \pm 35.5 ; \mathrm{CV}=70.95 \%)$ and $0.65 \mathrm{ppm}( \pm 0.44$, $\mathrm{CV}=85.10 \%$ ), respectively. The daily mean indoor levels of PM2.5 in the two chambers during the gestational period were $59.54 \mathrm{mg} / \mathrm{m}^{3}$ for the outside group (Out/Out group; \pm 29.5 ; $\mathrm{CV}=49.19 \%$; $\min -\max : 7-109)$ and $42.36 \mathrm{mg} / \mathrm{m}^{3}$ for the inside group (In/In group; $\pm 22.1 ; C V=33.22 \%$; $\min -\max$ : $6-51$ ), demonstrating a nearly 1.5 -fold difference $(p<0.0001)$. Maternal exposure was estimated by multiplying the total volume of inhaled air during gestation $(1120 \mathrm{~L}=19$ days $\times 1440 \mathrm{~min} \times$ minute volume of inhaled air taken to be
$0.041 \mathrm{~L} / \mathrm{min}$ ) by the mean $24 \mathrm{~h}$ concentration of PM 2.5. The estimated amount inhaled by Out/Out females was 66789.591 $\mathrm{mg} / \mathrm{m}^{3}$ during the whole gestation period and $3515.2 \mathrm{mg} / \mathrm{m}^{3}$ daily and for $\mathrm{In} / \mathrm{In}$ females was $47443.21 \mathrm{mg} / \mathrm{m}^{3}$ and 2497.01 $\mathrm{mg} / \mathrm{m}^{3}$, respectively.

Crown Rump Length and Birth Weights. The average crown rump length in $\mathrm{In} / \mathrm{In}$ and Out/Out was $32.17 \pm 25.2$ $\mathrm{mm}$ and $26.03 .17 \pm 3.9 \mathrm{~mm}$, respectively, demonstrating statistical differences $(p=0.0077)$. Also, the average birth weights in group $\mathrm{In} / \mathrm{In}$ and Out/Out was $1.7 \pm 0.2 \mathrm{~g}$ and $1.3 \pm 0.3 \mathrm{~g}$ demonstrating statistical differences $(p=0.0169)$. Crown rump length, fetus weight and litter weight were influenced by pregestational and gestational exposure periods. Total litter weight decreased in all three groups exposed to contaminated air. The apparent effects of AP on the three variables were significant. Post hoc tests detected significant differences in crown rump length, birth weights and litter weight between the groups exposed to AP and the In/In group.

Table I. The effects of exposure period (pregestational and gestational) on fetus and placenta. Data are expressed as mean \pm SD (CV)

\begin{tabular}{|c|c|c|c|c|c|}
\hline & $\operatorname{In} / \operatorname{In}$ & In/Out & Out/In & Out/Out & $p$-value \\
\hline \multicolumn{6}{|l|}{ FETUS } \\
\hline Crown Rump Length [mm] & $\begin{array}{c}32.17 \pm 5.2^{\mathrm{abc}} \\
\quad(16.17)\end{array}$ & $\begin{array}{c}26 \pm 2.52^{\mathrm{a}} \\
(9.70)\end{array}$ & $\begin{array}{c}25.66 \pm 3.99 \mathrm{~b} \\
\quad(15.55)\end{array}$ & $\begin{array}{c}26.03 \pm 3.96^{\mathrm{c}} \\
\quad(15.22)\end{array}$ & 0.0077 \\
\hline Fetal Weigth [g] & $\begin{array}{c}1.77 \pm 0.23^{\mathrm{abc}} \\
(13.19)\end{array}$ & $\begin{array}{l}1.30 \pm 19^{a} \\
(14.83)\end{array}$ & $\begin{array}{c}1.33 \pm 0.30^{\mathrm{b}} \\
(22.94)\end{array}$ & $\begin{array}{c}1.33 \pm 0.38^{c} \\
(29.28)\end{array}$ & 0.0064 \\
\hline Litter Weigth [g] & $\begin{array}{c}9.03 \pm 1.06^{\mathrm{abc}} \\
(11.76)\end{array}$ & $\begin{array}{c}7.64 \pm 0.64 \mathrm{a} \\
(8.49)\end{array}$ & $\begin{array}{c}7.25 \pm 0.75^{\mathrm{b}} \\
(10.37)\end{array}$ & $\begin{array}{c}7.19 \pm 0.70^{c} \\
(9.75)\end{array}$ & 0.0002 \\
\hline \multicolumn{6}{|l|}{ PLACENTA } \\
\hline Total volume $\left[\mathrm{m}^{3}\right]$ & $\begin{array}{c}0.49 \pm 0.18 \mathrm{ab} \\
\quad(24.09)\end{array}$ & $\begin{array}{c}0.46 \pm 0.08^{\mathrm{cd}} \\
(16.33)\end{array}$ & $\begin{array}{c}0.36 \pm 0.015^{\text {ace }} \\
(4.13)\end{array}$ & $\begin{array}{c}0.28 \pm 0.04^{\text {bde }} \\
(14.19)\end{array}$ & $<0.0001^{* * * * *}$ \\
\hline Cross-section area $\left[\mathrm{m}^{2}\right]$ & $\begin{array}{c}2.50 \pm 0.25^{\mathrm{a}} \\
(9.96)\end{array}$ & $\begin{array}{c}2.25 \pm 0.43 \mathrm{~b} \\
\quad(19.13)\end{array}$ & $\begin{array}{c}2.60 \pm 0.298^{\mathrm{bc}} \\
(11.44)\end{array}$ & $\begin{array}{c}2.07 \pm 0.21 \mathrm{ac} \\
\quad(10.21)\end{array}$ & 0.0439 \\
\hline Decidual zone [\%] & $\begin{array}{c}14.97 \pm 2.71^{\mathrm{a}} \\
(19.29)\end{array}$ & $\begin{array}{c}13.41 \pm 1.02 \\
(7.62)\end{array}$ & $\begin{array}{c}9.06 \pm 1.02^{\mathrm{ab}} \\
(11.34)\end{array}$ & $\begin{array}{c}14.40 \pm 2.21^{\mathrm{b}} \\
(15.38)\end{array}$ & 0.0283 \\
\hline Junctional zone [\%] & $\begin{array}{c}19.11 \pm 1.72 \mathrm{a}^{\mathrm{b}} \\
(9.04)\end{array}$ & $\begin{array}{c}26.57 \pm 2.22 \mathrm{ac}^{\mathrm{d}} \\
\quad(8.37)\end{array}$ & $\begin{array}{c}12.20 \pm 1.85^{\mathrm{bc}} \\
(15.16)\end{array}$ & $\begin{array}{c}15.64 \pm 0.80^{\mathrm{d}} \\
(5.14)\end{array}$ & $<0.0001^{* * * *}$ \\
\hline Labyrinth zone [\%] & $\begin{array}{c}66.81 \pm 0.99 \mathrm{a}^{\mathrm{b}} \\
(1.48)\end{array}$ & $\begin{array}{c}60.02 \pm 1.54 \mathrm{ac}^{\mathrm{d}} \\
(2.57)\end{array}$ & $\begin{array}{c}78.74 \pm 1.39^{\text {bce }} \\
(1.77)\end{array}$ & $\begin{array}{c}69.96 \pm 81.41^{\mathrm{de}} \\
(2.01)\end{array}$ & $<0.0001^{* * * * *}$ \\
\hline \multicolumn{6}{|l|}{ Blood vessels } \\
\hline $\mathrm{V}_{\mathrm{v}[\%]}$ & $\begin{array}{c}36.56 \pm 5.24^{\mathrm{a}} \\
(29.18)\end{array}$ & $\begin{array}{c}20.87 \pm 8.84 \mathrm{ab}^{\mathrm{c}} \\
\quad(24.30)\end{array}$ & $\begin{array}{c}31.26 \pm 7.60 \mathrm{~b} \\
\quad(42.33)\end{array}$ & $\begin{array}{c}29.47 \pm 8.60^{c} \\
(14.32)\end{array}$ & $<0.0001^{* * * * *}$ \\
\hline $\mathrm{S}_{\mathrm{v}} ;\left[\mathrm{mm}^{2 /} \mathrm{mm}^{3}\right]$ & $\begin{array}{c}21.94 \pm 8.64 \mathrm{a}^{\mathrm{b}} \\
(29.58)\end{array}$ & $\begin{array}{c}12.43 \pm 2.75 \mathrm{ac} \\
(30.59)\end{array}$ & $\begin{array}{c}13.85 \pm 4.24 \mathrm{~b} \\
(22.14)\end{array}$ & $\begin{array}{c}17.70 \pm 5.23^{c} \\
(39.39)\end{array}$ & $0.0002^{* *}$ \\
\hline $\mathrm{L}_{\mathrm{V}} ;\left[\mathrm{mm} / \mathrm{mm}^{3}\right]$ & $\begin{array}{c}1.01 \pm 0.46 \mathrm{ab} \\
(48.28)\end{array}$ & $\begin{array}{c}0.54 \pm 0.11 \mathrm{a} \\
(28.80)\end{array}$ & $\begin{array}{c}0.55 \pm 0.16^{\mathrm{b}} \\
(20.84)\end{array}$ & $\begin{array}{c}0.76 \pm 0.37 \\
(46.05)\end{array}$ & $0.0006^{* * *}$ \\
\hline \multicolumn{6}{|l|}{ CHORION } \\
\hline Length $\lceil\mu \mathrm{m}\rceil$ & $167 \pm 72.6 \mathrm{a}^{\mathrm{b}}$ & $126 \pm 40.3^{\mathrm{ac}}$ & $199 \pm 57.3 \mathrm{c}^{\mathrm{d}}$ & $136 \pm 34.5 \mathrm{bd}$ & $<0.0001^{* * * *}$ \\
\hline
\end{tabular}

* Similar letters are indicating statistical differences between groups. 
Volume measurement, planimetry and stereology. The total volume of the placenta was influenced by exposure to the AP. Statistical differences between the In/In and Out/ Out groups were detected $(p<0.0001)$. In addition, it was observed that the volume of the placenta decreased proportionally according to the amount of time of exposure during the pregestational and gestational periods. Post hoc analysis indicates that exposure to AP exclusively during pregnancy (In/Out) apparently has no significant effect on the volume of the placenta. We observed differences in the proportion of labyrinth $(p<0.0001)$, decidua $(p=0.0283)$ and junctional zone $(p<0.0001)$ between groups (Table I). Stereological analysis in the fetal capillary blood vessels and trophoblast of the labyrinth sub-compartment showed that there are no differences in the volume, area, and length of the capillary blood space between In/In and Out/Out groups. In addition, the volume of blood space decreased in the group exposed directly to AP exclusively during the gestational stage (In/Out), and conversely, the volume increased almost $12 \%$ in the group exposed directly to wood smoke pollution exclusively during the pregestational period (Out/In).

\section{DISCUSSION}

We have hypothesized that morphological changes in the rat placenta contribute to the reduction of fetal size associated with different periods of exposure to AP produced by wood smoke pollution pregestational and gestational period. According to our bibliographic search, this is the first study that describes the effects produced by pregestational and gestational exposure to AP caused by wood smoke pollution from residential heating on the morphology of the placenta and fetal size in a murine model. The methodology used aims to recreate the effects on the population, and especially on the reproductive system, of direct exposure to environmental pollution caused by smoke from wood combustion (indoor and outdoor). One of the strengths of this study is that the exposure was made directly in an environment whose main source of contamination is smoke from wood combustion, which represents $93 \%$ of emissions according to Díaz-Robles et al. Therefore, the results obtained are representative of the effects produced by this type of PM on the reproductive system.

Fetal weight and height decreased accompanied by decreases in volume and cross-sectional area of the placenta, however, although there was no difference in the proportion of the labyrinth region, the blood space decreased when the exposure occurred prior to o during pregnancy. Staying inside the chamber during the previous period and during gestation was associated with greater weights and sizes of fetuses, however, both the pre-pregnancy and gestation exposure periods resulted in morphological changes in the placenta. Pregestational exposure (Out/Out, Out/In) was associated with significant changes in placenta volume. Veras et al. attributed that the changes observed in placentas exposed to AP by PM produced by the combustion of diesel during the pre-pregnancy period, are the consequence of maternal vascular changes resulting from systemic changes or a compromised uterine environment prior to pregnancy. Pregestational exposure did not reduce the proportion of the labyrinth in the placenta. However, evidence suggests that it increases, if changes in the length of maternal and fetal blood vessels of the placenta occur. Regarding the placenta, the coefficients of variation indicated that most of the placental variables varied less $(2.57 \%-30.59 \%)$ in the group exposed to AP during the gestational period. In contrast, most of the placental variables varied more (15\% $-54 \%)$ in the group not exposed to AP during both periods. Regarding the greater interindividual variation observed in the In/Out and Out/In groups, Veras et al. attribute it to a worse adaptability to the polluted environment. However, fetal weight and height were higher in the group not exposed to AP (In/In), this may suggest that these conditions, with less AP, impose less environmental stress. Therefore, despite the existence of a microscopic process (pathological or inflammatory) that modifies the area of the tissues that make up the placenta and especially the vascular space, attributable to AP, these fail to induce macroscopic changes. Analysis of the evidence suggests that exposure to AP produced by wood smoke particles does not modify the macroscopic morphology of the placenta, however, it modifies the proportion of the vascular space in the placenta. A combination of fixation techniques and the use of stereological techniques without bias allowed obtaining precise estimates of the placental structural parameters, as demonstrated by the low standard deviations and coefficients of variation. This allowed performing more robust statistical analyzes and detecting significant statistical differences using adequate sample sizes. Previously, some investigations used only placental volume as a variable in experimental studies to characterize the variations produced by different treatments. The results presented here demonstrate that placental volume provides a rough estimate of placental development and morphology and does not discriminate differences in individual compartment development (such as labyrinth, junctional and decidua zones).

Therefore, they may not accurately reflect the functional capacity of the organ. For example, while In/In reaches a maximum placental volume of $0.49 \mathrm{~mm}^{3}$, the proportion that represents the labyrinth $(66.81 \%)$ continues to increase apparently at the expense of the decidua and the basal area. For Out/Out, there is a significant decrease in 
the placental volume and presents significant differences with In/In, however, between them they do not present significant differences in the proportions of the labyrinth, basal area and deciduous. This may be related to the differentiation of the trophoblast glycogen cells that arise from the basal area and then migrate to the decidua, becoming less abundant in the Out/Out basal area. During the gestation period, the increase in the volume of the labyrinth has been directly associated with the increase in the volume of the trophoblast and also by the volume occupied by the fetal capillaries and the maternal blood that flows through irregularly shaped spaces. In our study, In/In correlated the volume of the placenta with the volume of the fetal capillaries, demonstrating that direct non-exposure to PM from ambient AP influenced the dynamics of placental development in the rat. As the main site where the exchange of nutrients and gases between mother-fetus occurs, the labyrinth region plays a key role in fetal growth, the latter was demonstrated by the larger size of the rats in the In/In group compared to the other groups. This reinforces what was previously stated: That metric characteristics of blood vessels, such as the volume, surface and length, of the placenta, especially those present in the labyrinth, are important factors to consider during placental development and are also useful structures to assess the impact of the environment on the pregnancy.

In terms of area and volume, most of the development of the fetal capillaries and the maternal blood that flows through irregularly shaped spaces occurred in the group without direct exposure to AP during the pregestational and gestational period (In/In), however, this did not show statistical differences with the group with direct exposure during the pregestational and gestational period (Out/Out). Georgiades et al. (2002) stated that if changes in maternal arterial blood pressure, and in the speed of blood flow are not considered, the volume of maternal blood that can circulate through the placenta, is greater in those placentas not directly exposed to the environmental particulate material. This suggests that the development of fetal capillaries, and especially their metric characteristics, can determine an optimal and efficient maternal-fetal blood flow until the end of gestation. This coincides with that observed in female rats that were exposed only during the gestational pre-period, also coinciding with the presence of a placenta. All these antecedents suggest that the exposure to the particulate material produced by the wood smoke that is generated by the combustion of firewood for residential heating during the gestational period is the most likely to induce morphofunctional quantitative changes in the placenta and therefore could affect the fetus health. Mayhew et al. (1993) and Coan et al. (2004) emphasized the importance of placental development after 14.5 days, particularly of the placenta, since they present continuously higher volumes of fetal blood (lengthening and branching of vessels) useful for maternofetal exchange in order to obtain enough nutrients and oxygen for fetal growth. It is important to consider that the large surface areas of blood vessels are accompanied by thin exchange barriers, therefore in this type of placenta the diffusion distance is minimized and the passive gas exchange area is maximized. The In/In group presented the largest surface area of blood vessels in the labyrinth region, this has been associated by Mayhew et al. (1993) with decreased interhemal membrane thicknesses and an increased diffusion capacity necessary for normal growth of the embryonic tissue.

In conclusion, this study demonstrated that long-term outdoor exposure to AP from smoke from combustion of residential wood for heating affects fetal health in rat, decreasing the absolute volume of the entire placenta and the placental interface between the mother and fetus, decreasing the total volume of blood vessels present in the labyrinth region of the placenta and affecting the size of the fetus. Finally, differential studies in the vessels of the mother and fetus and maternal-fetal hemodynamics are necessary to determine if umbilical and placental blood flows are compromised.

Funding: DI-PUCV 039.378/2019, Direccioón de Investigación, Pontificia Universidad Católica de Valparaíso.

SALINAS, P.; VEUTHEY, C.; RUBIO, I.; BONGIORNO, A. \& ROMERO, I. Exposure La exposición a la contaminación por humo de leña durante el período pregestacional de la rata tiene efectos sobre el volumen de la placenta y el tamaño del feto. Int. J. Morphol., 38(5):1356-1364, 2020.

RESUMEN: Estudios en humanos demostraron que la exposición prenatal a la polución del aire urbano influye en el desarrollo fetal y aumenta la incidencia de resultados adversos de la gestación y algunas enfermedades postnatales. Sin embargo, la mayoría de ellos fueron realizados en entornos donde la principal fuente de emisión de material particulado, fue la combustión de petróleo por vehículos a motor e industrias, ignorando los efectos producidos por el humo de leña producido por la calefacción intradomiciliaria. Hipotetizamos respecto a que los cambios de la placenta contribuirían a la disminución del tamaño fetal relacionado a los períodos de exposición al humo de leña durante los periodos pregestacional y gestacional. El objetivo del estudio fue investigar los efectos cuantitativos de la exposición al humo de leña sobre la morfología macroscópica y microscópica en placenta de ratas. Para probar esto, ratas preñadas fueron expuestas durante los períodos pregestacional y gestacional a la contaminación por humo de leña en ambientes interiores y exteriores. A los 19 días de gestación, las placentas fueron obtenidas por cesárea y fueron preparadas para un análisis histológico, planimétrico y estereológico. Fue estimado el volumen absoluto y las proporciones de los compartimentos placentarios. Además, fueron calculados estimadores estereológicos en capilares fetales del laberinto y trofoblasto. La longitud, el peso del feto y el peso de la camada fueron influenciados por los períodos de exposi- 
ción pregestacional y gestacional. La exposición a la contaminación por humo de leñá durante el período pregestacional tuvo un efecto significativo en el volumen de la placenta y, en consecuencia, en la altura del feto. En conclusión, este estudio demostró que la exposición a largo plazo al humo de leña afecta la salud del feto, disminuyendo el volumen absoluto de la placenta, además, afecta la interfaz placentaria entre la madre y feto, disminuyendo el volumen total de vasos sanguíneos presentes en la región del laberinto placentario y por consecuente afectando el tamaño del feto.

PALABRAS CLAVE: Contaminación; Humo; Humo de Leña; Placenta; Estereología; Rata; Temuco.

\section{REFERENCES}

Boso, Á.; Álvarez, B.; Oltra, C.; Garrido, J.; Muñoz, C. \& Hofflinger, Á. Out of sight, out of mind: participatory sensing for monitoring indoor air quality. Environ. Monit. Assess., 192(2):104, 2020.

Carré, J.; Gatimel, N.; Moreau, J.; Parinaud, J. \& Léandri, R. Does air pollution play a role in infertility?: a systematic review. Environ. Health, 16(1):82, 2017.

Cereceda-Balic, F.; Fadic, X.; Llanos, A. L.; Dominguez, A. M.; Guevara, J. L.; Vidal, V.; Díaz-Robles, L. A.; Schiappacasse, L. N. \& Etcharren, P. Obtaining polycyclic aromatic hydrocarbon concentration ratios and molecular markers for residential wood combustion: Temuco, a case study. J. Air Waste Manag. Assoc., 62(1):44-51, 2012.

Coan, P. M.; Ferguson-Smith, A. C. \& Burton, G. J. Developmental dynamics of the definitive mouse placenta assessed by stereology. Biol. Reprod., 70(6): 1806-13, 2004.

Díaz-Robles, L. A.; Ortega, J. C.; Fu, J. S.; Reed, G. D.; Chow, J. C.; Watson, J. G. \& Moncada-Herrera, J. A. A hybrid ARIMA and artificial neural networks model to forecast particulate matter in urban areas: The case of Temuco, Chile. Atmos. Environ., 42(35):8331-40, 2008.

Dockery, D. W. \& Pope 3rd, C. A. Acute respiratory effects of particulate air pollution. Annu. Rev. Public Health, 15:107-32, 1994.

Dockery, D. W.; Cunningham, J.; Damokosh, A. I.; Neas, L. M.; Spengler, J. D.; Koutrakis, P.; Ware, J. H.; Raizenne, M. \& Speizer, F. E. Health effects of acid aerosols on north american children: respiratory symptoms. Environ. Health Perspect., 104(5):500-5, 1996.

Dorph-Petersen, K. A.; Nyengaard, J. R. \& Gundersen, H. J. Tissue shrinkage and unbiased stereological estimation of particle number and size. $J$. Microsc., 204(Pt. 3):232-46, 2001

Georgiades, P.; Ferguson-Smith, A. C. \& Burton, G. J. Comparative developmental anatomy of the murine and human definitive placentae. Placenta, 23(1):3-19, 2002.

Glinianaia, S. V.; Rankin, J.; Bell, R.; Pless-Mulloli, T. \& Howel, D. Particulate air pollution and fetal health: A systematic review of the epidemiologic evidence. Epidemiology, 15(1):36-45, 2004.

Gouveia, N.; Bremner, S. A. \& Novaes, H. M. D. Association between ambient air pollution and birth weight in São Paulo, Brazil. J. Epidemiol. Community Health, 58(1):11-7, 2004.

Heinrich, J.; Hoelscher, B.; Wjst, M.; Ritz, B.; Cyrys, J. \& Wichmann, H. Respiratory diseases and allergies in two polluted areas in East Germany. Environ. Health Perspect., 107(1):53-62, 1999.

IQ Air. 2019 World Air Quality Report. Region \& City PM2.5 Ranking. IQ Air, 2020. Available from: https://www.airvisual.com/world-mostpolluted-cities/world-air-quality-report-2019-en.pdf

Maisonet, M.; Bush, T. J.; Correa, A. \& Jaakkola, J. J. Relation between ambient air pollution and low birth weight in the Northeastern United States. Environ. Health Perspect., 109(Suppl. 3):351-6, 2001.

Maisonet, M.; Correa, A.; Misra, D. \& Jaakkola, J. J. K. A review of the literature on the effects of ambient air pollution on fetal growth. Environ. Res., 95(1):106-15, 2004.
Mayhew, T. M. A stereological perspective on placental morphology in normal and complicated pregnancies. J. Anat., 215(1):77-90, 2009.

Mayhew, T. M.; Jackson, M. R. \& Boyd, P. A. Changes in oxygen diffusive conductances of human placentae during gestation (10-41 weeks) are commensurate with the gain in fetal weight. Placenta, 14(1):51-61, 1993.

Ministerio de Salud (MINSAL). Ley $n^{\circ}$ 20380/2009 sobre Protección de Animales. Santiago de Chile, Subsecretaría de Salud Pública, Ministerio de Salud, Gobierno de Chile, 2009. Available from: http://www.leychile.cl/ Navegar?idNormal $=1006858$

Ministerio de Salud (MINSAL). Prohíbe Emisión de Humos Visibles y Uso de Calefactores, Calderas y Artefactos Residenciales Particulares, que Utilicen como Combustible Leña u Otro Dendroenergético Sólido en Comunas que Indica. Resolución 6296 EXENTA; Resolución JI-6296 EXENTA. Santiago de Chile, Ministerio de Salud, Gobierno de Chile, 2015.

Mohorovic, L. First two months of pregnancy--Critical time for preterm delivery and low birthweight caused by adverse effects of coal combustion toxics. Early Hum. Dev., 80(2):115-23, 2004.

National Research Council (US) Committee for the Update of the Guide for the Care and Use of Laboratory Animals. Guide for the Care and Use of Laboratory Animals. $8^{\text {th }}$ ed. Washington (DC), National Academies Press (US), 2011. Available from: https://www.ncbi.nlm.nih.gov/books/ NBK54050

Nolen, R. S. AVMA board approves Panel on Euthanasia report: updated guidelines cover more species and methods. J. Am. Vet. Med. Assoc., 239(10):1269, 2011

Oyarzún, G. M. Air pollution an its effects on health. Rev. Chil. Enferm. Respir., 26(1):16-25, 2010.

Raja, S.; Chandrasekaran, S. R.; Lin, L.; Xia, X.; Hopke, P. K. \& Valsaraj, K. T. Analysis of beta attenuation monitor filter rolls for particulate matter speciation. Aerosol Air. Qual. Res., 17(1):14-23, 2017.

Reyes, R.; Schueftan, A.; Ruiz, C. \& González, A. D. Controlling air pollution in a context of high energy poverty levels in southern Chile: Clean air but colder houses? Energy Policy, 124:301-11, 2019.

Ritz, B.; Wilhelm, M.; Hoggatt, K. J. \& Ghosh, J. K. C. Ambient air pollution and preterm birth in the environment and pregnancy outcomes study at the University of California, Los Angeles. Am. J. Epidemiol., 166(9):104552, 2007.

Romieu, I.; Gouveia, N.; Cifuentes, L. A.; de Leon, A. P.; Junger, W.; Vera, J.; Strappa, V.; Hurtado-Díaz, M.; Miranda-Soberanis, V.; Rojas-Bracho, L.; et al. Multicity study of air pollution and mortality in Latin America (The ESCALA Study). Res. Rep. Health Eff. Inst., (171):5-86, 2012.

Saldiva, P. H.; Pope 3rd, C. A.; Schwartz, J.; Dockery, D. W.; Lichtenfels, A. J.; Salge, J. M.; Barone, I. \& Bohm, G. M. Air pollution and mortality in elderly people: a time-series study in Sao Paulo, Brazil. Arch. Environ. Health, 50(2):159-63, 1995

Sanhueza, P. A.; Torreblanca, M. A.; Diaz-Robles, L. A.; Schiappacasse, L. N.; Silva, M. P. \& Astete, T. D. Particulate air pollution and health effects for cardiovascular and respiratory causes in Temuco, Chile: a woodsmoke-polluted urban area. J. Air Waste Manag. Assoc., 59(12):1481-8, 2009.

Corresponding author:

Paulo Salinas

Laboratory of Animal \& Experimental Morphology

Institute of Biology, Faculty of Sciences,

Pontificia Universidad Católica de Valparaíso

Av. Universidad \# 330

Curauma 3100000

Valparaíso - CHILE

Received: 28-03-2020

Accepted: 03-04-2020

Email: paulo.salinas@pucv.cl

ORCID: https://orcid.org/0000-0003-2273-0904 